\title{
Efektivitas penyuluhan terhadap tingkat pengetahuan mencuci tangan siswa MTs Miftahul Ulum 2 Kubu Raya
}

\author{
Chris Monica Mizmor Narwastu, ${ }^{1, *}$, Abror Irsan², Agus Fitriangga ${ }^{2}$ \\ ${ }^{1}$ Program Studi Kedokteran, Fakultas Kedokteran, Universitas Tanjungpura, Kalimantan Barat, Indonesia \\ ${ }^{2}$ Departemen Ilmu Kesehatan Masyarakat, Fakultas Kedokteran, Universitas Tanjungpura, Kalimantan Barat, Indonesia \\ *Korespondensi: chrismonicamn@student.untan.ac.id
}

\begin{abstract}
Abstrak
Latar belakang: Cuci tangan adalah salah satu cara mencegah penyakit infeksi berbasis lingkungan. Siswa di sekolah bebas melakukan aktivitas di sekolah sehingga dapat memicu perpindahan patogen dari satu individu ke individu lain. Salah satu upaya untuk meningkatkan pengetahuan masyarakat terutama siswa mengenai pentingnya mencuci tangan ialah dengan diadakannya penyuluhan menggunakan media audiovisual. Metode: Penelitian ini menggunakan metode penelitian pre-eksperimen dengan rancangan one group pretest-posttest. Populasi penelitian seluruh siswa di MTs Miftahul Ulum 2 Desa Punggur Kecil, Kecamatan Sungai Kakap, Kabupaten Kubu Raya. Subjek penelitian diambil melalui total sampling dengan jumlah 37 siswa-siswi. Analisis dilakukan menggunakan Uji McNemar. Hasil: Sebelum penyuluhan, responden yang berpengetahuan baik berjumlah 15 orang, sedangkan setelah penyuluhan, seluruh responden berpengetahuan baik. Hasil Uji McNemar menunjukkan terdapat efektivitas penyuluhan tentang cuci tangan menggunakan media audiovisual sebelum dan sesudah penyuluhan (nilai $\mathrm{p}=0,000$ ). Kesimpulan: Penyuluhan tentang cuci tangan menggunakan media audiovisual efektif dalam meningkatkan pengetahuan siswa di MTs Miftahul Ulum 2 Kubu Raya.
\end{abstract}

Kata kunci: cuci tangan, tingkat pengetahuan, penyuluhan

\section{Effectiveness of counseling toward handwashing knowledge level among MTs Miftahul Ulum 2 Kubu Raya students}

\begin{abstract}
Background: Handwashing is one way to prevent environmental-based infections. Students at schools are free to carry out activities at school and pathogens can be freely transferred from one individual to another. An effort to increase public knowledge about the importance of handwashing is through counseling using audiovisual media. Methods: This study used a pre-experimental design with one group pretest-posttest. The study subjects were all students at MTs Miftahul Ulum 2 in Kubu Raya. Subjects were obtained by total sampling, with a total of 37 students participated. Analysis was done using McNemar Test. Results: Before counseling, 15 respondents had good knowledge, and after counseling, all respondents had good knowledge. McNemar test showed the effectiveness of counseling using audiovisual media on level of knowledge about handwashing ( $p$ value $=0,000)$. Conclusions: Counseling using audiovisual media effectively increases the level of knowledge about handwashing in MTs Miftahul Ulum 2 Kubu Raya.
\end{abstract}

Keywords: handwashing, level of knowledge, counseling

\section{Pendahuluan}

Indonesia belum menargetkan secara nasional tingkat higiene bangsa dibandingkan beberapa negara lain yang sudah menerapkan layanan dasar sanitasi seperti menyediakan fasilitas mencuci tangan baik di daerah perkotaan maupun pedesaan. ${ }^{1}$ Akan tetapi,
Indonesia sudah merupakan satu dari 20 negara yang turut aktif berpartisipasi dalam kampanye global yang dibentuk oleh PBB perihal mencuci tangan dengan sabun sebagai bentuk preventif penyakit yang mengakibatkan penurunan kualitas hidup manusia. ${ }^{2}$

Penelitian yang pernah dilakukan melaporkan bahwa cuci tangan memakai sabun adalah salah satu 
cara mencegah penyakit infeksi berbasis lingkungan. Siswa di sekolah bebas bergaul dan bersosialisasi dengan kelompok sebayanya dalam melakukan aktivitas di sekolah sehingga mengharuskan para siswa untuk bersentuhan baik secara sengaja dan tidak sengaja. Hal tersebut memicu perpindahan patogen dari satu individu ke individu yang lainnya. ${ }^{3}$

Penyuluhan kesehatan merupakan aktivitas pendidikan kesehatan dengan cara memberikan pesan, membangun keyakinan sehingga masyarakat tidak hanya menjadi sadar, tahu dan paham, serta dapat ikut dan berbuat sesuatu sesuai anjuran dan berkaitan dengan kesehatan. Tingkat keberhasilan suatu penyuluhan kesehatan bergantung kepada komponen pembelajarannya. Salah satu komponen dari proses pembelajaran tersebut adalah media penyuluhan. ${ }^{4}$

Alat edukasi yang beberapa tahun terakhir semakin banyak digunakan adalah media audiovisual dan bersaing dengan textbook tradisional. ${ }^{5}$ Salah satu media yang menyediakan informasi atau pesan secara audio dan visual adalah media audiovisual. Perkembangan teknologi yang semakin maju membuat pemakaian media audiovisual semakin terjangkau. Penyuluhan dengan media audiovisual dapat dijadikan jawaban bagi kebutuhan pemberian penyuluhan secara sistematis kepada masyarakat dengan fokus pada meningkatnya pengetahuan masyarakat. ${ }^{6}$

Profil Puskesmas Punggur menggambarkan keadaan sosial ekonomi masyarakat binaan Puskesmas Punggur sebagian besar penduduk dengan status sosial menengah ke bawah dan hanya terdapat enam sarana pendidikan tingkat menengah termasuk MTs Miftahul Ulum 2 Desa Punggur Kecil Kecamatan Sungai Kakap Kabupaten Kubu Raya. Lingkungan wilayah kerja Puskesmas Punggur digambarkan sebagai daerah dengan beriklim tropis, sebagian kondisi lingkungan adalah tanah rawa, dan sebagian lainnya sebagai lahan pertanian dan perkebunan. Keadaan ini sangat berpotensi untuk berkembangnya penyakit berbasis lingkungan sebagai contoh berkembangnya beberapa vektor seperti nyamuk serta bibit penyakit lainya. ${ }^{7}$ Berkaitan dengan hal tersebut yang telah diuraikan, pentingnya pengetahuan tentang cuci tangan perlu diketahui oleh seluruh lapisan masyarakat termasuk siswa MTs Miftahul Ulum 2 Desa Punggur Kecil Kecamatan Sungai Kakap Kabupaten Kubu Raya.

\section{Metode}

Penelitian ini menggunakan desain penelitian preeksperimen dengan menggunakan rancangan one group pretest-posttest design. Penelitian ini dilaksanakan di MTs Miftahul Ulum 2 Desa Punggur Kecil, Kecamatan Sungai Kakap, Kabupaten Kubu Raya pada Februari 2020. Jumlah sampel pada penelitian ini adalah 37 orang, dengan kriteria inklusi yaitu pelajar aktif MTs di MTs Miftahul Ulum 2 Desa Punggur Kecil Kecamatan Sungai Kakap serta bersedia menjadi subjek penelitian. Kriteria eksklusi adalah pelajar yang tidak hadir secara lengkap saat pengambilan data pretest dan posttest. Data primer diperoleh dari pengisian identitas diri, penilaian penelitian, kuesioner Hasil penelitian akan diolah dengan SPSS 26 dan menggunakan uji McNemar.

\section{Hasil}

Distribusi partisipan berdasarkan karakteristik umum subjek penelitian disajikan dalam Tabel 1.

Tabel 1. Karakteristik umum subjek penelitian

\begin{tabular}{lcc}
\hline Karakteristik & $\mathrm{N}=37$ & $\%$ \\
\hline Usia (tahun) & 5 & 13,5 \\
12 & 7 & 18,9 \\
13 & 13 & 35,2 \\
14 & 10 & 27,0 \\
15 & 1 & 2,7 \\
16 & 1 & 2,7 \\
17 & 12 & 32,4 \\
\hline Kelas & 12 & 32,4 \\
VII & 13 & 35,2 \\
VIII & & \\
IX & 17 & 45,9 \\
\hline Jenis Kelamin & 20 & 54,1 \\
Laki-laki & &
\end{tabular}

Jumlah subjek penelitian adalah 37 orang dan dikelompokkan berdasarkan karakteristik usia, kelas, dan jenis kelamin. Rentang usia pada penelitian berkisar 12 tahun hingga 17 tahun, usia termuda dalam penelitian adalah 12 tahun dan usia tertua 17 tahun. Kelompok subjek penelitian yang memiliki distribusi terbesar adalah yang berusia 14 tahun sebanyak 13 orang (35,2\%). Subjek penelitian berdasarkan kelas di MTs terdiri dari kelas VII, kelas 
VIII, dan kelas IX. Kelompok subjek penelitian yang memiliki distribusi terbesar adalah subjek penelitian kelas IX sebanyak 13 orang $(35,2 \%)$. Kelompok subjek penelitian berdasarkan jenis kelamin adalah laki-laki sebanyak 17 orang $(45,9 \%)$ dan perempuan sebanyak 20 orang (54,1\%). Kelompok subjek penelitian yang memiliki distribusi terbesar adalah perempuan sebanyak 20 orang $(54,1 \%)$.

Hasil uji normalitas dengan uji normalitas Kolmogorov-Smirnov menunjukkan bahwa sampel dari 37 responden penelitian berdistribusi tidak normal. Hasil diolah menggunakan Uji McNemar dalam program SPSS 26.0. Distribusi perubahan frekuensi sebelum dan sesudah penyuluhan terhadap tingkat pengetahuan tentang cuci tangan tercantum pada tabel 4.10. Hasil uji McNemar menunjukkan nilai signifikansi 0,000 , maka secara statistik penyuluhan menggunakan media audiovisual memberikan efektivitas yang signifikan terhadap tingkat pengetahuan tentang cuci tangan pada responden. Hasil uji normalitas dapat dilihat pada Tabel 2.

Tabel 2. Perbandingan tingkat pengetahuan responden sebelum dan sesudah penyuluhan mengenai cuci tangan

\begin{tabular}{|c|c|c|c|c|c|}
\hline & \multicolumn{2}{|c|}{$\begin{array}{c}\text { Sesudah } \\
\text { Penyuluhan }\end{array}$} & \multirow[t]{2}{*}{ Total } & \multirow{2}{*}{$\begin{array}{c}\mathrm{Uji} \\
\mathrm{McNe} \\
\text { mar }\end{array}$} \\
\hline & & Baik & $\begin{array}{c}\text { Kurang } \\
\text { Baik }\end{array}$ & & \\
\hline \multirow{4}{*}{$\begin{array}{l}\text { Sebe- } \\
\text { lum } \\
\text { Penyu- } \\
\text { luhan }\end{array}$} & Baik & 15 & 0 & 15 & \multirow{4}{*}{0,000} \\
\hline & Kurang & 22 & 0 & 22 & \\
\hline & Baik & & & & \\
\hline & Total & 37 & 0 & 37 & \\
\hline
\end{tabular}

\section{Pembahasan}

Hasil penelitian yang telah dilakukan menyatakan bahwa penyuluhan secara statistik memberikan efektivitas dalam meningkatkan pengetahuan peserta didik mengenai cuci tangan. Terjadi peningkatan pengetahuan baik dari 15 responden sebelum penyuluhan menjadi 37 responden setelah penyuluhan. Hal ini menunjukkan bahwa terjadi peningkatan jumlah responden yang memiliki tingkat pengetahuan yang baik mengenai cuci tangan sebanyak 22 orang. Penyuluhan bertujuan meningkatkan tingkat pengetahuan siswa mengenai cuci tangan sehingga dapat menerapkannya dalam kehidupan sehari-hari.

Pengetahuan manusia sebagian besar diperoleh dari mata dan telinga dan merupakan hasil dari tahu setelah individu melakukan pengindraan terhadap hal tertentu. Objek dalam proses pendidikan mempunyai intensitas yang paling tinggi untuk mempersepsikan bahan edukasi. Penyampaian melalui kata-kata saja dianggap kurang efektif. Media dapat dijadikan salah satu prinsip proses edukasi. Media dapat dijadikan bantuan dalam melakukan penyuluhan supaya penyampaian pesan kesehatan dapat disampaikan jelas dan tepat sasaran. ${ }^{8}$

Oktarisa dalam penelitiannya menyatakan bahwa materi mengenai pengetahuan dapat diperoleh dari pendidikan formal maupun non formal. Sumber informasi dapat berupa berbagai macam media sehingga seseorang dapat dengan mudah mengakses informasi dan lebih cepat mendapat pengetahuan. ${ }^{9}$ Media audiovisual dianggap menarik dalam pemberian penyuluhan kesehatan dan dapat dijadikan alat bantu edukasi yang penggunaanya menstimulasi indra pendengaran dan penglihatan selain itu juga dapat diputar berulang-ulang. Hasil penelitian Sri Nurhaningsih didapatkan pengaruh yang signifikan pada kelompok intervensi. Penelitian yang telah dilakukan sejalan dengan teori bahwa media audiovisual dapat melibatkan dua indra sebagai alat pembelajaran yaitu indra pendengaran dan penglihatan, sehingga semakin banyak alat indra yang terlibat untuk menerima dan mengolah informasi, semakin besar kemungkinan isi informasi dapat dimengerti dan dipertahankan dalam ingatan. ${ }^{10}$

Selaras dengan penelitian yang dilakukan oleh Kristina, dkk bahwa pengetahuan pada kelompok yang mendapat pendidikan kesehatan dengan menggunakan media audiovisual sebelumnya akan mengalami perubahan yang bermakna. ${ }^{11}$ McMichael menggambarkan pentingnya untuk lebih memahami hasil intervensi air, sanitasi dan kebersihan di sekolah yang terkait dengan penyakit dan pendidikan berbasis sekolah sehingga diperlukannya intervensi yang efektif. ${ }^{12}$ Penelitian oleh Bowmann dkk, mengemukakan bahwa mencuci tangan adalah langkah pencegahan paling penting untuk mengurangi penyakit menular. Beberapa penelitian telah menunjukkan efektivitas intervensi pendekatan multikomponen seperti pemberian penyuluhan berupa materi, pengingat dan pengetahuan timbalbalik manfaat kebersihan untuk meningkatkan kebiasaan cuci tangan. ${ }^{13}$

Pengetahuan yang diterima pada akhirnya diharapkan dapat memengaruhi perilaku. Berkaitan 
dengan perilaku, apabila berdasar kepada pengetahuan akan lebih diingat daripada perilaku yang tidak berdasar kepada pengetahuan. ${ }^{14}$ Penelitian yang telah dilakukan oleh Staniford menunjukkan bahwa intervensi membantu mengembangkan kebiasaan kebersihan masyarakat yang lebih baik sejak anak-anak adalah fokus kesehatan masyarakat yang sangat penting karena bakteri penyebab infeksi dapat hidup di tubuh seseorang dan di lingkungan sekitarnya. Intervensi yang lebih efektif harus secara bersamaan mendorong kebersihan pribadi (misalnya mencuci tangan) untuk menunjukkan pengembangan intervensi di masa depan guna meningkatkan kesehatan masyarakat yang dirancang untuk peningkatan kebersihan tangan dan desinfektan lingkungan di lingkungan yang kemungkinan mencakup anak-anak. ${ }^{15}$

Tingkat pengetahuan responden sesudah penyuluhan mengalami peningkatan dan responden keseluruhan adalah dalam kategori baik setelah dilaksanakan penyuluhan. Penyuluhan diberikan guna tercapainya tingkat pengetahuan yang pertama, yakni tingkat tahu sehingga responden dapat mengingat suatu materi yang sebelumnya telah dipelajari guna mengukur peningkatan pengetahuan setelah dilakukannya intervensi penyuluhan. Efektivitas pengetahuan sebelum dan sesudah penyuluhan tentang cuci tangan telah diuji menggunakan Uji McNemar sehingga diperoleh nilai p 0,000. Dengan demikian dapat disimpulkan bahwa penyuluhan mengenai cuci tangan yang dilakukan di MTs Miftahul Ulum 2 Desa Punggur Kecil Kecamatan Sungai Kakap Kabupaten Kubu Raya terbukti signifikan terhadap tingkat pengetahuan siswa. Hasil uji tersebut menunjukkan bahwa hipotesis kerja dapat diterima dibuktikan dengan analisis yang menunjukkan perbedaan yang bermakna dari setiap variabel yang diuji.

\section{Kesimpulan}

Berdasarkan hasil penelitian, maka dapat disimpulkan bahwa penyuluhan menggunakan media audiovisual secara statistik memberikan efektivitas yang signifikan terhadap tingkat pengetahuan siswa mengenai cuci tangan di MTs Miftahul Ulum 2 Desa Punggur Kecil Kecamatan Sungai Kakap Kabupaten Kubu Raya.

\section{Daftar Pustaka}

1. World Health Organization. Water, sanitation and hygiene: Global status report 2019 [Internet]. WHO.int 2019 [cited 2019 Oct 16]. Available from: https://apps.who.int/iris/bitstream/handle/10665/3264 44/9789241516297-eng.pdf?ua $=1$

2. Kemenkes RI. Infodatin: Perilaku mencuci tangan pakai sabun di Indonesia. Kementerian Kesehatan RI; 2015.

3. Pokja Sanitasi Kabupaten Kubu Raya. Buku putih sanitasi Kabupaten Kubu Raya Provinsi Kalimantan Barat. Pokja Sanitasi Kabupaten Kubu Raya; 2013.

4. Suharsono T, Kumboyono, Wihastuti TA, Susmarini D, Lestari R, Kristanto H, et al. Efektifitas audiovisual sebagai media penyuluhan kesehatan terhadap peningkatan pengetahuan dan sikap ibu dalam tatalaksana balita dengan diare di dua Rumah Sakit Kota Malang. Jurnal Ilmu Keperawatan; 2013.

5. Pujol J, Blanco-Hinojo L, Martínez-Vilavella G, CanuMartín L, Pujol A, Pérez-Sola V, et al. Brain activity during traditional textbook and audiovisual-3D learning. Brain Behav [Internet]. 2019 [cited 2019 Oct 18];9(10). Available from: https://onlinelibrary.wiley.com/doi/abs/10.1002/brb3. 1427

6. Wirawan S, Abdil KL, Sulendri NKS. Penyuluhan dengan media audiovisual dan konvensional terhadap pengetahuan $\mathrm{ibu}$ anak balita. Jurnal Kesehatan Masyarakat.; 2014.

7. Profil Kesehatan Puskesmas Punggur Tahun 2015; 2016.

8. Notoadmojo S. Promosi kesehatan dan perilaku kesehatan. Revisi 2012. Jakarta: Rineka Cipta; 2012.

9. Ar-Rasily OK, Dewi PK. Faktor-faktor yang mempengaruhi tingkat pengetahuan orang tua mengenai kelainan genetik penyebab disabilitas intelektual di Kota Semarang Semarang: Universitas Diponegoro; 2016.

10. Hartiningsih SN. Pengaruh pendidikan kesehatan dengan media audiovisual dan media booklet terhadap perilaku caregiver dalam mencegah tuberkulosis pada anggota keluarga. Yogyakarta: STIKes Surya Global; 2018.

11. Wea KB, Hidayati L. Pendidikan kesehatan dengan media audiovisual meningkatkan perilaku ibu dalam penanganan infeksi saluran pernafasan akut pada balita di Kelurahan Lebijaga Kabupaten Ngada. Surabaya: Universitas Airlangga; 2018.

12. McMichael C. Water, sanitation and hygiene in schools in low-income countries: A review of evidence of impact. Int $\mathrm{J}$ Environ Res Public Health. 2019;16(3):359.

13. Bowman LG, Hardesty SL, Sigurdsson SO, McIvor M, Orchowitz PM, Wagner LL, et al. Utilizing groupbased contingencies to increase hand washing in a large human service setting. Behav Anal Pract. 2019;12(3):600-11.

14. Notoadmojo S. Metode penelitian kesehatan. Jakarta: Rineka Cipta; 2012.

15. Staniford LJ, Schmidtke KA. A systematic review of hand-hygiene and environmental-disinfection interventions in settings with children. BMC Public Health. 2020;20(1):195. 